\title{
Influence of Urbanization and Industries on the Pollution of Rivers of Gjilan Municipality, Kosovo
}

\author{
V. M. Beluli* \\ University of Mitrovica "Isa Boletini”, Faculty of Food Technology, Department of Technology, Kosovo
}

This work is licensed under a

\begin{abstract}
Gilan $\left(42^{\circ} 28^{\prime} 08^{\prime \prime} \mathrm{V}, 21^{\circ} 27^{\prime} 48^{\prime \prime} \mathrm{L}\right)$ is one of the seven largest cities in Kosovo. Throughout the city flow three rivers: Mirusha and Stanishor which mix and discharge into the largest river called Morava. The reason for the research of these rivers is the extreme pollution resulting from the discharge of industrial waters. Analysis of these rivers shows that they are extremely polluted and some physicochemical parameters are not in accordance with the regulations of the European Union (EU) and the World Health Organization (WHO). Parameters analysed are: $\mathrm{pH}, \mathrm{CW}, \mathrm{NTU}, \mathrm{DO}, \mathrm{COD}, \mathrm{BOD} 5, \mathrm{~A}-\mathrm{HCl}_{1} \mathrm{HCO}_{3}, \mathrm{GH}, \mathrm{CS}, \mathrm{Cl}^{-}$, $\mathrm{Cl}_{2}, \mathrm{Ca}^{2+}, \mathrm{Mg}^{2+}, \mathrm{NO}_{2}^{-}, \mathrm{NO}_{3}{ }^{-}, \mathrm{PO}_{4}{ }^{3-}$, and $\mathrm{NH}_{3}{ }^{-}$.
\end{abstract}

\section{Keywords}

Rivers, industries, extreme pollution, physicochemical parameters, EU, WHO

\section{Introduction}

The increment in the world's population and the overwhelming industrial development has made water supply a problem on our planet, thus imposing the need for rapid long-term solutions. ${ }^{1}$ Today it is acknowledged that environmental protection should be given the highest priority, because the preservation of the continuity of life depends on it. Our knowledge of the environment is increasing constantly, and we now have enough knowledge about the chemical composition of our planet and developing processes. Resources (natural resources) of land are finite, and the exploitation and contamination of its systems on the regenerative possibilities have important implications for life on it. ${ }^{2}$ Water pollution from chemical substances can be divided into two groups: inorganic and organic chemical contamination. Inorganic pollutants include: nitrates, nitrites, sulphates, heavy metals, etc. Organic pollutants include oil and its derivatives, such as soaps, detergents, textile industry effluents, paper, phenols, radioactive materials, etc. ${ }^{3}$ Water is a substance with a number of unique properties of great environmental significance. Water quality standards have legislative support and specify the characteristics for water. ${ }^{4}$ In order to prove the quality of these rivers, physicochemical parameters were determined by international methods, as presented in the Table 1.

Alkalinity refers to the capability of water to neutralize acid. This is really an expression of buffering capacity. A buffer is a solution to which an acid can be added without changing the concentration of available $\mathrm{H}^{+}$ions (without changing the $\mathrm{pH}$ ) appreciably. Ammonia appears in different contrition in groundwater, surface water, and wastewater. Its appearance in water and in loess is described as a result of the reduction of nitrogen-containing organic matter, deamination of amines, hydrolysis of corn, etc., where all

*Valdrin M. Beluli, Food Technology Engineer e-mail: valdrin_beluli@hotmail.com nitrogen appears as $\mathrm{NH}_{4}$ or $\mathrm{NH}_{3}$. Orthophosphates $\left(\mathrm{PO}_{4}{ }^{3-}\right)$ are soluble salts of phosphoric acid, which dissolve into tinctures in humans, depending on the $\mathrm{pH}$ of the environment. Orthophosphates are used as artificial fertilizers in land, which dissolve and flow into surface water.

Chlorides are anions distributed in surface water and wastewater, while their concentration in natural water varies greatly. The chloride ion $\left(\mathrm{Cl}^{-}\right)$with appropriate oxidizing agents has a higher redox potential than chlorine $\left(\mathrm{Cl}_{2}\right){ }^{5}$ The characteristic of primary importance in many water systems is the amount of dissolved oxygen (DO), which can be quickly expended by the oxidation of organic material. In addition, the oxygen in water can even be consumed by bio-oxidation of dissolved ammonia or chemical iron oxidation $\mathrm{Fe}^{2+}$ or $\mathrm{SO}_{3}{ }^{2-}$.

Nitrites, which are produced by nitrogen oxidation, are polyanion monovalent $\left(\mathrm{NO}_{3}^{-}\right)$. Most of the metal nitrates are soluble in water and appear in very small quantities. They appear in trace amounts in surface and groundwater. The main source of nitrite ions $\left(\mathrm{NO}_{2}^{-}\right)$in unpolluted surface water is the process of mineralization of organic matter and nitrification from bacteria. ${ }^{6}$ The most important parameters for determination of organic pollution, also applied in wastewater and surface water, is 5-day biochemical oxygen demand (BOD5). BOD is not a measurement of a specific pollutant, but the measurement of the amount of oxygen required by aerobic bacteria and other microorganisms for the decomposition of organic matter. Most of all, organic substances, which are biologically difficult to oxidize, can be chemically oxidized. Thus, chemical oxygen demand (COD) is generally higher than BOD. ${ }^{7}$ Water containing a larger amount of dissolved salts of alkaline earth metals is called strong water as opposed to mild water in which the amount of these salts is small. ${ }^{1}$ The calcium ions are very important only for euchroites. The quantity of calcium in organisms is used only for support and to build structures such as teeth. Magnesium ions are ions dominated by $2^{+}$in the cytoplasm and the only ions 
found free, unrelated to the minimum levels. ${ }^{8}$ Determination of these physicochemical parameters in water allows us to determine the pollution from industry, urban sewage, farms, etc. Extreme pollution is an expression of biological pollution from industry when BOD and COD exceeds the allowed values prescribed by European Union (EU) and World Health Organization (WHO) standards.

In ancient times, water pollution was low, perhaps because of smaller population. The industrial revolution and large population growth have led to serious environmental pollution. ${ }^{9}$

Table 1 - Permissibility criteria for physicochemical parameters according to $\mathrm{WHO}$ (ref. ${ }^{10}$, p. 35 )

Tablica 1 - Dopušteni kriteriji za fizikalno-kemijske parametre prema SZO-u (lit. ${ }^{10}$, str. 35)

\begin{tabular}{|c|c|c|}
\hline $\begin{array}{l}\text { Parameters } \\
\text { Parametri }\end{array}$ & $\begin{array}{l}\text { Symbol/unit } \\
\text { Simbol/jedinica }\end{array}$ & $\begin{array}{l}\text { WHO } \\
\text { SZO }\end{array}$ \\
\hline $\mathrm{pH}$ & $\mathrm{pH}$ & $6.8-8.5$ \\
\hline $\begin{array}{l}\text { conductivity of water } \\
\text { vodljivost vode }\end{array}$ & $\mathrm{CW} / \mathrm{S} \mathrm{m}^{-1}$ & $<50$ \\
\hline $\begin{array}{l}\text { nephelometric turbidity unit } \\
\text { nefelometarska jedinica mutnoće }\end{array}$ & NTU & 10 \\
\hline $\begin{array}{l}\text { dissolved oxygen } \\
\text { otopljeni kisik }\end{array}$ & $\mathrm{DO} / \mathrm{mgl}^{-1}$ & $>5$ \\
\hline $\begin{array}{l}\text { chemical oxygen demand } \\
\text { kemijska potrošnja kisika }\end{array}$ & $\mathrm{COD} / \mathrm{mgl}^{-1}$ & 10 \\
\hline $\begin{array}{l}\text { 5-day biochemical oxygen } \\
\text { demand } \\
\text { petodnevna biokemijska } \\
\text { potrošnja kisika }\end{array}$ & $\mathrm{BOD} 5 / \mathrm{mgl}^{-1}$ & $<3$ \\
\hline $\begin{array}{l}\text { alkalinity } \\
\text { akalnost }\end{array}$ & $\mathrm{A}-\mathrm{HCl} / \mathrm{mgl}^{-1}$ & 10.5 \\
\hline $\begin{array}{l}\text { bicarbonates } \\
\text { bikarbonati }\end{array}$ & $\mathrm{HCO}_{3}^{-} / \mathrm{mgl}^{-1}$ & 630 \\
\hline $\begin{array}{l}\text { general hardness } \\
\text { ukupna tvrdoća }\end{array}$ & $\mathrm{GH} /{ }^{\circ} \mathrm{dH}$ & 30 \\
\hline $\begin{array}{l}\text { calcium } \\
\text { kalcij }\end{array}$ & $\mathrm{Ca}^{2+} / \mathrm{mgl}^{-1}$ & $<200$ \\
\hline $\begin{array}{l}\text { magnesium } \\
\text { magnezij }\end{array}$ & $\mathrm{Mg}^{2+} / \mathrm{mgl}^{-1}$ & $<50$ \\
\hline $\begin{array}{l}\text { chlorides } \\
\text { kloridi }\end{array}$ & $\mathrm{Cl}^{-} / \mathrm{mgl}^{-1}$ & $<200$ \\
\hline $\begin{array}{l}\text { chlorine } \\
\text { klor }\end{array}$ & $\mathrm{Cl}_{2} / \mathrm{mgl}^{-1}$ & $0.2-0.5$ \\
\hline $\begin{array}{l}\text { nitrites } \\
\text { nitriti }\end{array}$ & $\mathrm{NO}_{2}^{-} / \mathrm{mgl}^{-1}$ & 0.6 \\
\hline $\begin{array}{l}\text { nitrates } \\
\text { nitrati }\end{array}$ & $\mathrm{NO}_{3}^{-} / \mathrm{mgl}^{-1}$ & 10 \\
\hline $\begin{array}{l}\text { phosphates } \\
\text { fosfati }\end{array}$ & $\mathrm{PO}_{4}{ }^{3-} / \mathrm{mgl}^{-1}$ & 0.2 \\
\hline $\begin{array}{l}\text { ammonia } \\
\text { amonijak }\end{array}$ & $\mathrm{NH}_{3}^{-} / \mathrm{mgl}^{-1}$ & 0.05 \\
\hline
\end{tabular}

\section{Experimental}

\subsection{Chemicals}

Ethylenediaminetetraacetic acid (EDTA), Nitri Ver 3 reagent (USA), Nitra Ver 5 reagent (USA), Ammonia Salicylate reagent (USA), Ammonia Cyanurate reagent (USA), Phos Ver 3 reagent (USA), DPD Total Chlorine reagent (USA), $\mathrm{AgNO}_{3}\left(c=0.01 \mathrm{~mol} \mathrm{I}^{-1}\right), \mathrm{HCl}\left(c=0.01 \mathrm{moll}^{-1}\right)$, buffer, indicator (black erythromycin), indicator (methylorange), indicator (phenolphthalein), indicator (black murexide), $\mathrm{NaOH}\left(c=2 \mathrm{~mol} \mathrm{I}^{-1}\right)$, methylene chloride, $\mathrm{K}_{2} \mathrm{Cr}_{2} \mathrm{O}_{7}$, $\mathrm{H}_{2} \mathrm{SO}_{4} 98 \%$, glucose.

\subsection{Physicochemical parameters and methods of analysis}

Absorption spectrometry in the ultraviolet and visible region is based on the electromagnetic radiation absorption of molecules in the UV spectra of $160-400 \mathrm{~nm}$ and VIS 400-780 $\mathrm{nm}$ range. UV-VIS radiation absorption causes the excitation of the electrons of chemical bonds by passing the molecules to higher energy levels. ${ }^{11}$ The absorption of UV-VIS radiation from complex molecules and inorganic salts of transitional metals, as well as of lanthanides and actinides, causes the molecule to move from its basal to its excited state. ${ }^{12}$ The Hach Model DR/2010 Spectrophotometer is a microprocessor-controlled single-beam instrument for colorimetric testing in the laboratory or in the field. The instrument is precalibrated for over 120 different colorimetric measurements and allows convenient calibrations for user-entered and future Hach methods. ${ }^{13}$

The $\mathrm{pH}$, conductivity of water $(\mathrm{CW})$, and dissolved oxygen (DO) were determined at the sampling points using a portable multiparameter analyser. Other chemical parameters were determined according to the standard analytical methods for the examination of water and wastewater according to the WHO and EU standards (see Table 1). The value of $\mathrm{pH}$ was determined using a portable multiparameter analyser, WTW 3010. Conductivity of water (CW), also known as specific conductivity, represents the ability of water to convey electricity, and is related to the concentration of ionized substances in water. ${ }^{2} \mathrm{CW}$ was determined with WTW Cond 3110, DO was determined with WTW Oxi $315 \mathrm{i}$, and NTU was determined with 2100N ISC Turbidimeter (ISO Method 7027).

The chemical oxygen demand (COD) represents the amount of oxygen from organic matter, which is subjected to oxidation by any strong oxidizing agent. ${ }^{6}$ COD was determined in the instrument Photometer Winlab on $\lambda=610 \mathrm{~nm}$. The standard was prepared with $3 \mathrm{ml}$ of glucose, $2 \mathrm{ml}$ of $\mathrm{K}_{2} \mathrm{Cr}_{2} \mathrm{O}_{7}$, and $5 \mathrm{ml}$ of $\mathrm{H}_{2} \mathrm{SO}_{4}$. Blank was prepared with $3 \mathrm{ml}$ of distilled water, $2 \mathrm{ml}$ of $\mathrm{K}_{2} \mathrm{Cr}_{2} \mathrm{O}_{7}$, and $5 \mathrm{ml}$ of $\mathrm{H}_{2} \mathrm{SO}_{4}$, and sample with $3 \mathrm{ml}$ of contaminated water, $2 \mathrm{ml} \mathrm{K}_{2} \mathrm{Cr}_{2} \mathrm{O}_{7}$, and $5 \mathrm{ml} \mathrm{H}_{2} \mathrm{SO}_{4}$ in the cuvette. Before being placed in the photometer, they were up to $150{ }^{\circ} \mathrm{C}$ for $2 \mathrm{~h}$.

As a result of the oxidation of organic matter by microorganisms, the biochemical oxygen demand in the well-preserved water sample decreases in time. Empirically, BOD5 is the amount of the consumed oxygen needed to oxidize the organic matter into the sample. The most commonly 
used test, BOD5, is based on a 5-day incubation of sample at $20^{\circ} \mathrm{C} \pm 1{ }^{\circ} \mathrm{C}$. The tool used was "OxiTop", which was filled with water up to $250 \mathrm{ml}$.

Nitrite $\left(\mathrm{NO}_{2}{ }^{-}\right)$concentration was determined using Nitri Ver 3 reagent (Nitrite Test $2-150 \mathrm{mgl}^{-1}$, Method 8153), and the absorbance level was then measured using a spectrophotometer ( $\mathrm{HACH}$ DR 900, USA). Nitrate $\left(\mathrm{NO}_{3}{ }^{-}\right)$ concentration was determined using Nitra Ver 5 reagent (Nitrate Test 0-30 $\mathrm{mg} \mathrm{l}^{-1}$, Method 8039), and the absorbance level was then measured using a spectrophotometer (HACH DR/2010, USA) at $\lambda=500 \mathrm{~nm}$. Nitrogen ammonia $\left(\mathrm{NH}_{3}{ }^{-}\right)$concentration was determined using ammonia salicylate reagent in first step, and then using ammonia cyanurate reagent (Nitrogen Ammonia Test $0-0.50 \mathrm{mgl}^{-1}$, Method 8155) in second step. The absorbance level was then measured using a spectrophotometer $(\mathrm{HACH}$ DR/2010, USA) at $\lambda=655 \mathrm{~nm}$.

Phosphate $\left(\mathrm{PO}_{4}{ }^{-3}\right)$ concentration was determined using Phos Ver 3 reagent (Phosfate Test $0-2.50 \mathrm{mg} \mathrm{I}^{-1}$, Method 8048), and the absorbance level was then measured using a spectrophotometer (HACH DR/2010, USA) at $\lambda=890 \mathrm{~nm}$.

For the determination of chlorine $\left(\mathrm{Cl}_{2}\right)$, DPD Total Chlorine reagent (Chlorine Test 0.02-2 $\mathrm{mgl}^{-1}$, Method 8167) was used. The absorbance level did not exist and was then measured using a Pocket Colorimeter II ( $\mathrm{HACH}$, USA).

The determination of chlorides was carried out in an Erlenmeyer flask containing $100 \mathrm{ml}$ of water sample (adjust $\mathrm{pH} \mathrm{7-10} \mathrm{if} \mathrm{necessary).} \mathrm{With} \mathrm{the} \mathrm{addition} \mathrm{of} 1 \mathrm{ml}$ of $\mathrm{K}_{2} \mathrm{CrO}_{4}$, the sample turned yellowish. Titration was done with silver nitrate $\left(\mathrm{AgNO}_{3}\left(\mathrm{C}=0.01 \mathrm{moll}^{-1}\right)\right)$ and it stopped at the moment when the solution gets light red. ${ }^{1}$ The value of the chlorides in the sample was calculated according to Eq. (1):

$$
\mathrm{Cl}^{-} / \mathrm{mg} \mathrm{I} I^{-1}=35.453 \cdot \mathrm{c} \cdot \frac{\left(V_{1}-V_{2}\right)}{V_{\mathrm{s}}}
$$

where $V_{1}$ is the volume of the titre for the sample $(\mathrm{ml}), V_{2}$ is the volume of the titre for blind sample $(\mathrm{ml}), \mathrm{C}$ is molarity $\mathrm{AgNO}_{3}\left(c=0.01 \mathrm{moll}^{-1}\right)$, and $V_{\mathrm{s}}$ is the volume of the sample used (100 $\mathrm{ml}$ in our case).

Water sample alkalinity $(A)$ is the measurement of its capacity to neutralize the acids. Water accumulation is mainly due to weak acid salts. In $100 \mathrm{ml}$ of the analysed sample, 4 drops of phenolphthalein were added. If the $100 \mathrm{ml}$ solution became purple, that meant the water contained bases due to $\mathrm{pH}$ above 8.3 , and if the solution did not turn purple, 2 to 3 drops of methylorange were added, which turned the solution yellow. The solution was then titrated with $\mathrm{HCl}\left(c=0.01 \mathrm{moll}^{-1}\right)$ until it turned orange, and the amount of titre used was recorded. ${ }^{1}$

Water hardness or general hardness $(\mathrm{GH})$ was achieved by pouring $100 \mathrm{ml}$ of sample into a 250-ml flask, adding $2-5 \mathrm{ml}$ of buffer and indicator (black erythromycin) in very small quantities. Following the addition of the indicator, the solution became red or light red, and the titration was done with complexon III or EDTA $\left(c=0.01 \mathrm{moll}^{-1}\right)$ until the solution changed its colour to intensive blue. ${ }^{1}$ The calculation was made based on Eq. (2):

$$
\mathrm{GH} / \mathrm{mg} \mathrm{I}^{-1}=\frac{V_{\mathrm{EDTA}} \cdot C_{\mathrm{EDTA}} \cdot 56 \cdot 1000}{V},
$$

where $V_{\text {EDTA }}$ is the titration volume $(\mathrm{ml})$ with ethylenediaminetetraacetic acid, $C_{\mathrm{EDTA}}$ is the concentration of EDTA $\left(C=0.01 \mathrm{moll}^{-1}\right)$, and $V_{\mathrm{s}}$ is the volume of the sample used.

Carbonate strength (CS) is defined as the alkalinity to methylorange. A volume of $100 \mathrm{ml}$ water sample was transferred to 500-ml Erlenmeyer flask and 2-3 drops of methylene chloride were added. The titration was performed with standard solution $\mathrm{HCl}\left(c=0.01 \mathrm{~mol} \mathrm{I}^{-1}\right)$ until the colour changed to orange. The analysis results were calculated in German degrees $\left({ }^{\circ} \mathrm{dH}\right)$ water hardness scale according to Eq. (3)

$$
\mathrm{CS} /{ }^{\circ} \mathrm{dH}=2.8 \cdot V_{\mathrm{HCL}} \cdot \mathrm{C}_{\mathrm{HCL}},
$$

where 2.8 value is the constant, $V_{\mathrm{HCL}}$ is consumed volume of $\mathrm{HCl}$, and $C_{\mathrm{HCL}}$ is the concentration of $\mathrm{HCl}$ $\left(c=0.01 \mathrm{~mol} \mathrm{I}^{-1}\right)$.

First, we get $100 \mathrm{ml}$ of water, add $5 \mathrm{ml}$ of buffer solution (in this case $\mathrm{NaOH}\left(c=2 \mathrm{~mol} \mathrm{I}^{-1}\right)$ ) and a black murexide indicator (black murexide is prepared from ammonia purities mixed with $\mathrm{NaCL}\left(c=0.01 \mathrm{~mol} \mathrm{I}^{-1}\right)$, and titrated with EDTA $\left(c=0.01 \mathrm{moll}^{-1}\right)$ to change the colour from red to purple. The titration should be carried out for 5 min after the addition of $\mathrm{NaOH} .{ }^{1}$ The determination of $\mathrm{Ca}^{2+}$ was calculated by the following Eq. (4):

$$
\mathrm{Ca}^{2+} / \mathrm{mg} \mathrm{I}^{-1}=\frac{V_{\text {EDTA }} \cdot C_{\text {EDTA }} \cdot 56 \cdot 1000}{V_{s}},
$$

where $V_{\text {EDTA }}$ is the volume $(\mathrm{ml})$ of the titre with ethylenediaminetetraacetic acid, $C_{\mathrm{EDTA}}$ is the concentration of EDTA $\left(c=0.01 \mathrm{moll}^{-1}\right)$, and $V_{\mathrm{s}}$ is the volume of the sample used.

Determination of $\mathrm{Mg}^{2+}$ was calculated with the following Eq. (5):

$$
\mathrm{Mg}^{2+} / \mathrm{mgl}^{-1}=\frac{\mathrm{GH} /{ }^{\circ} \mathrm{dH}-\mathrm{Ca}^{2+} / \mathrm{mgl}^{-1}}{10} \cdot 7.19
$$

\section{Results and discussion}

\subsection{Location of the analysed samples}

Mirusha and Stanishor rivers are surface waters, characterized by low volumes during the summer, while during the winter season, the waters of these rivers are more voluminous. These two rivers flow into the rapid-flowing river called "Morava e Binçës". These rivers are highly polluted because sewage and industrial waters are discharged into them (Fig. 1). The source of the Mirusha River is in the village of Koretisht, and is called "holy water" by the inhabitants of this village, but the problem is that during its flow, it collects various impurities and sewage. The Stanishor River is also polluted, while its source is clean. The river rises in the suburbs of Gjilan and takes the name Stanishor accord- 


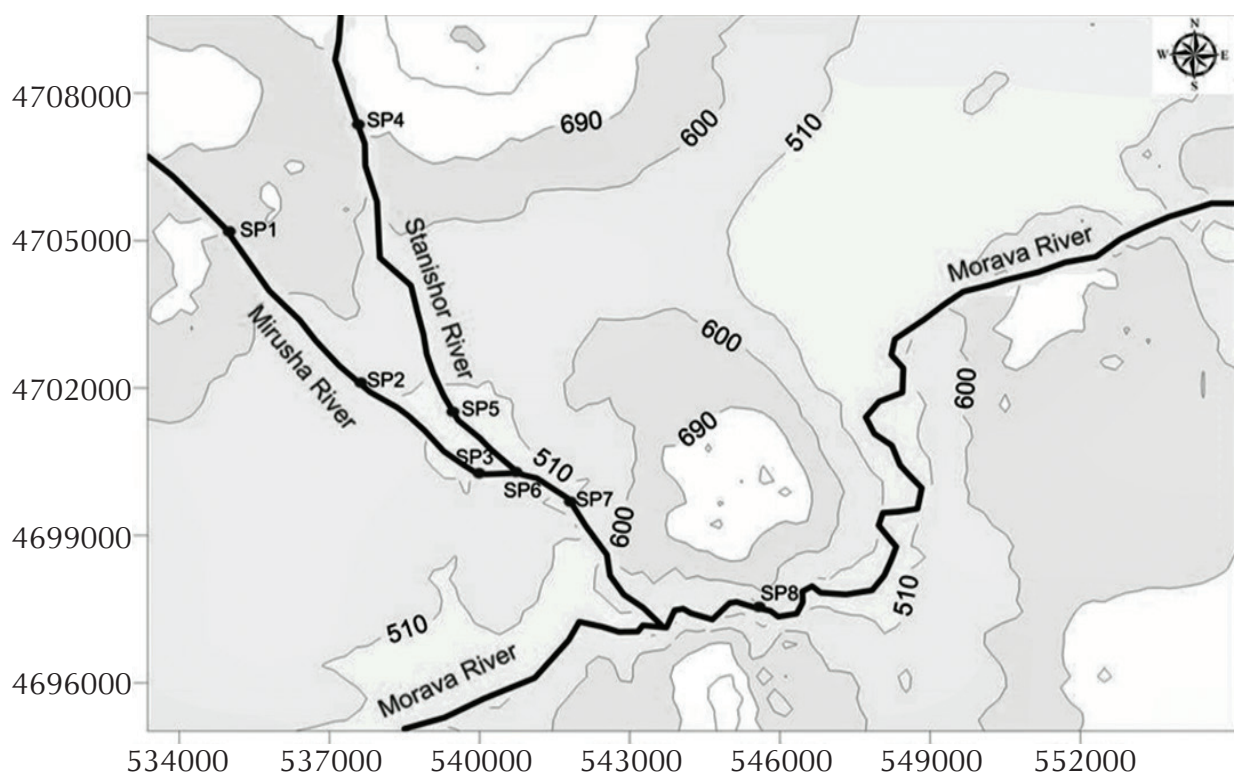

Fig. 1 - Monitoring network of the river research area $\left(\right.$ ref. $^{10}{ }^{1}$, p. 21$)$

Slika 1 - Mreža za praćenje područja istraživanja rijeka (lit. ${ }^{10}$, str. 21)

ing to the village from which it springs. Morava e Binçës belongs to the Black Sea basin. It joins the Western Morava, which merges and flows into the Danube and then into the Black Sea. The description of the sampling locations of the Mirusha, Stanishor, and Morava rivers is very important in explaining the network of monitoring the physical and chemical parameters of these rivers. Sample $\mathrm{SP}_{1}$ belongs to the Mirusha River resource, sample $\mathrm{SP}_{2}$ was taken after the river passes Koretisht village, while sample $\mathrm{SP}_{3}$ was taken after the river passes the town of Gijlan. Sample $\mathrm{SP}_{4}$ was taken from the Stanishor River basin, and sample $\mathrm{SP}_{5}$ was taken after passing the Gjilan City. Sample $\mathrm{SP}_{6}$ was taken at the merging point of the two rivers. Sample $\mathrm{SP}_{7}$ was taken further downstream from sample $\mathrm{SP}_{6}$, and sample $\mathrm{SP}_{8}$ belongs to the Morava River.

\subsection{Results of $\mathrm{pH}$ determination}

These contaminated rivers have $\mathrm{pH}$ varying between 7.2 and 7.39, which does not express concern. In $\mathrm{SP}_{1}, \mathrm{pH}$ was 7.2 , but as the water flows and passes through the village, the $\mathrm{pH}$ of $\mathrm{SP}_{2}$ increased to 7.28. In addition, the $\mathrm{pH}$ of $\mathrm{SP}_{3}$ was 7.33. Again, $\mathrm{pH}$ increased to 7.33. $\mathrm{SP}_{4}$ was taken from the Stanishor River, which was $\mathrm{pH} 7.38$, but at the entrance to the city, after passing through the village and the city, $\mathrm{pH}$ increased to 7.39 in sample $\mathrm{SP}_{5}$, while in $\mathrm{SP}_{6}$, which was taken where the two rivers merge, the $\mathrm{pH}$ reduced to 7.37. $\ln \mathrm{SP}_{7}$, the $\mathrm{pH}$ was reduced to 7.25, while in $\mathrm{SP}_{8}$, of the Morava River the $\mathrm{pH}$ rose again to 7.3 (Table 2). The $\mathrm{pH}$ of these water samples are in accordance with $\mathrm{WHO}$ and EU regulations (Table 1).

\subsection{Results for the conductivity of water (CW)}

Conductivity of water (CW) from the source of the Mirusha River to the exit of the city increased from 14.9 to
$28.5 \mathrm{~S} \mathrm{~m}^{-1}$. In sample $\mathrm{SP}_{1}, \mathrm{CW}$ was $14.9 \mathrm{~S} \mathrm{~m}^{-1}$, in $\mathrm{SP}_{2}$ at the exit of the village $\mathrm{CW}$ increased to $24.3 \mathrm{~S} \mathrm{~m}^{-1}$, while in $\mathrm{SP}_{3} \mathrm{CW}$ was $28.5 \mathrm{~S} \mathrm{~m}^{-1}$ (Fig. 1). Thus, an increase in electrical conductivity of the water is obvious. On the other hand, in the source of the Stanishor stream $\mathrm{SP}_{4}, \mathrm{CW}$ was 31.7, while in $\mathrm{SP}_{5}$ the $\mathrm{CW}$ dropped to $27.3 \mathrm{~S} \mathrm{~m}^{-1}$, but at the merging point of the two rivers at $\mathrm{SP}_{6}$ the value of $\mathrm{CW}$ was $24.8 \mathrm{~S} \mathrm{~m}^{-1}$, which was lower in comparison to samples $\mathrm{SP}_{3}$ and $\mathrm{SP}_{5}$. CW value of sample $\mathrm{SP}_{7}$ was $27.5 \mathrm{~S} \mathrm{~m}^{-1}$, so we see it rising, while in Morava River the $\mathrm{CW}$ value in sample $\mathrm{SP}_{8}$ was $24.1 \mathrm{~S} \mathrm{~m}^{-1}$, which is lower compared to $\mathrm{SP}_{2}, \mathrm{SP}_{3}, \mathrm{SP}_{4}, \mathrm{SP}_{5}, \mathrm{SP}_{6}$, and $\mathrm{SP}_{7}$. CW values in these rivers are in accordance with EU and WHO regulations (Table 1).

\subsection{Results for nephelometric turbidity unit (NTU)}

Nephelometric turbidity unit (NTU) is a measure of relative purity or water turbidity. Turbidity is a feature of absorbing light or distributing it from suspended water. ${ }^{14}$

In the $\mathrm{SP}_{1}$ sample, the value of NTU was 0.295 at the Mirusha River site and within the allowed criteria, but the obtained value of NTU in $\mathrm{SP}_{2}$ sample was 42.2, which is not in accordance with EU and WHO regulations (Table 1). The sample $\mathrm{SP}_{3}$ taken out of the city had NTU value of 57.8 , so while passing through the village and the city, NTU value increases more and more due to uncontrolled urban and industrial wastewater. In sample $\mathrm{SP}_{4}$ or in the Stanishor River basin, the NTU value was 0.626 , but that river in the city or sample $\mathrm{SP}_{5}$ had NTU value 53.6. NTU value at the merging point of the two rivers, sample $\mathrm{SP}_{6}$, was 14.5, thus, a decrease in turbulence is obvious. In sample $\mathrm{SP}_{7}, \mathrm{NTU}$ was 66.1 , and the Morava River $\mathrm{SP}_{8}$ sample NTU value was 27.5 (Fig. 1).

(i) In first group of samples $\mathrm{SP}_{1}$ and $\mathrm{SP}_{4}$, the NTU values are in the accordance with the EU and WHO regulations. 
(ii) In the second set of samples $-\mathrm{SP}_{2}, \mathrm{SP}_{3}, \mathrm{SP}_{5}, \mathrm{SP}_{6}, \mathrm{SP}_{7}$, and $\mathrm{SP}_{8}, \mathrm{NTU}$ values are not in accordance with the $\mathrm{EU}$ and $\mathrm{WHO}$ regulations.

\subsection{Results for dissolved oxygen (DO)}

Dissolved oxygen (DO) is a very important parameter for biotin. A too low amount of oxygen in water suggests that the water sample taken as in our case may exhibit a very high degree of pollution due to the very high presence of microorganisms. In the $\mathrm{SP}_{1}$ sample taken at the Mirusha River reservoir, DO was $4.67 \mathrm{mgl}^{-1}$ indicating that it is below the $\mathrm{EU}$ and $\mathrm{WHO}$ allowed value $>5 \mathrm{mg} \mathrm{I}^{-1}$. In the sample $\mathrm{SP}_{2}$ at the exit of the Koretisht village, DO value was $1.18 \mathrm{mg} \mathrm{l}^{-1}$, suggesting a significant decrease in DO. In the $\mathrm{SP}_{3}$ sample at the exit of the Mirusha River from Gijlan, DO value was $0.61 \mathrm{mgl}^{-1}$. Comparison of $\mathrm{SP}_{1}$ and $\mathrm{SP}_{3}$ dissolved oxygen (DO) samples revealed a drop to
$4.06 \mathrm{mgl}^{-1}$, and this decline is due to the microorganisms that need oxygen to perform their biological and chemical activities. In the $\mathrm{SP}_{4}$ sample at the Stanishor River basin, DO value was $4.53 \mathrm{mg} \mathrm{I}^{-1}$ indicating that it is below the allowed value, while in the $\mathrm{SP}_{5}$ sample at the exit of the city of Gilan, DO value was $0.6 \mathrm{mgl}^{-1}$. Therefore, if we compare $\mathrm{DO}$ from $\mathrm{SP}_{1}$ and $\mathrm{SP}_{5}$, the value of $\mathrm{DO}$ decreased to $3.93 \mathrm{mg} \mathrm{l}^{-1}$. At the merging point of the rivers Mirusha and Stanishor in sample $\mathrm{SP}_{6}$, DO value was $1.32 \mathrm{mg} \mathrm{l}^{-1}$. In sample $\mathrm{SP}_{7}$ (Fig. 1), DO value was $3.36 \mathrm{mgl}^{-1}$, whereas in sample $\mathrm{SP}_{8}$ of Morava River, DO was $0.32 \mathrm{mgl}^{-1}$. The highest and the lowest values in the mentioned locations are divided into two groups:

(i) The first group in the $\mathrm{SP}_{1}$ and $\mathrm{SP}_{4}$ samples are not in accordance with the $\mathrm{EU}$ and $\mathrm{WHO}$ regulations (Table 2 ).

(ii) The second $\mathrm{SP}_{2}, \mathrm{SP}_{3}, \mathrm{SP}_{4}, \mathrm{SP}_{5}, \mathrm{SP}_{6}, \mathrm{SP}_{7}$ and $\mathrm{SP}_{8}$ sampling group is not in accordance with the $\mathrm{EU}$ and $\mathrm{WHO}$ regulations (Tables 1 and 2).

Table 2 - Physicochemical parameters of the Stanishor, Mirusha and Morava rivers (ref. ${ }^{6}$, p. 35)

Tablica 2 - Fizikalno-kemijski parametri rijeka Stanishor, Mirusha i Morava (lit. ${ }^{6}$, str. 35)

\begin{tabular}{|c|c|c|c|c|c|c|c|c|}
\hline & \multicolumn{8}{|c|}{$\begin{array}{c}\text { Samples } \\
\text { Uzorci }\end{array}$} \\
\hline & $\mathrm{SP}_{1}$ & $\mathrm{SP}_{2}$ & $\mathrm{SP}_{3}$ & $\mathrm{SP}_{4}$ & $\mathrm{SP}_{5}$ & $\mathrm{SP}_{6}$ & $\mathrm{SP}_{7}$ & $\mathrm{SP}_{8}$ \\
\hline${ }^{\circ} \mathrm{C}$ & 9 & 28 & 24 & 11 & 27 & 23 & 22.5 & 23.4 \\
\hline odour & No & Yes & Yes & No & Yes & Yes & Yes & Yes \\
\hline $\mathrm{pH}$ & 7.2 & 7.28 & 7.33 & 7.38 & 7.39 & 7.37 & 7.25 & 7.3 \\
\hline $\mathrm{CW} / \mathrm{S} \mathrm{m}^{-1}$ & 14.9 & 24.3 & 28.5 & 31.7 & 27.3 & 24.8 & 27.5 & 24.1 \\
\hline NTU & 0.295 & 42.2 & 57.8 & 0.626 & 53.6 & 14.5 & 66.1 & 27.5 \\
\hline $\mathrm{DO} / \mathrm{mgl}^{-1}$ & 4.67 & 1.18 & 0.61 & 4.53 & 0.6 & 1.32 & 3.36 & 0.32 \\
\hline $\mathrm{COD} / \mathrm{mgl}^{-1}$ & 0.12 & 3.36 & 1.7 & 4.94 & 0.13 & 3.1 & 2.7 & 1.34 \\
\hline \multirow{5}{*}{$\mathrm{BOD}_{5} / \mathrm{mgl}^{-1}$} & 0 & 0.9 & 0.8 & 0 & 0.6 & 0.6 & 0 & 12 \\
\hline & 0 & 13 & 11 & 0 & 10 & 14 & 0.1 & 19 \\
\hline & 0 & 17 & 15 & 0 & 13 & 16 & 0.4 & 25 \\
\hline & 0 & 19 & 17 & 0 & 15 & 20 & 0.3 & 27 \\
\hline & 0 & 20 & 18 & 0 & 17 & 21 & 0.2 & 29 \\
\hline $\mathrm{A}-\mathrm{HCl} / \mathrm{mgl}^{-1}$ & 6.1 & 6.8 & 6.7 & 5.5 & 7 & 7.5 & 7.8 & 5.6 \\
\hline $\mathrm{HCO}_{3}^{-} / \mathrm{mgl}^{-1}$ & 372.1 & 414.8 & 408.7 & 335.5 & 427 & 457.5 & 475.8 & 341.6 \\
\hline $\mathrm{GH} /{ }^{\circ} \mathrm{dH}$ & 19.3 & 17.41 & 17.92 & 19.48 & 18.42 & 20.16 & 21 & 15.28 \\
\hline $\mathrm{Ca}^{2+} / \mathrm{mgl}^{-1}$ & 61.7 & 126.2 & 129.05 & 122.88 & 140.28 & 140.8 & 140.2 & 102 \\
\hline $\mathrm{Mg}^{2+} / \mathrm{mgl}^{-1}$ & 56.7 & 20.6 & 21.6 & 31.02 & 18.9 & 26.4 & 30.07 & 21.9 \\
\hline $\mathrm{CS} /{ }^{\circ} \mathrm{dH}$ & 17.08 & 19.04 & 18.7 & 15.4 & 19.6 & 21 & 21.8 & 15.6 \\
\hline $\mathrm{Cl}^{-} / \mathrm{mgl}^{-1}$ & 12.3 & 72 & 68 & 29.9 & 51.9 & 52.2 & 73.9 & 36 \\
\hline $\mathrm{Cl}_{2} / \mathrm{mgl}^{-1}$ & 0 & 0.21 & 0.26 & 0 & 0.01 & 0.07 & 0.39 & 0.19 \\
\hline $\mathrm{NO}_{2}^{-} / \mathrm{mgl}^{-1}$ & 1 & 16 & 11 & 4 & 13 & 12 & 2 & 13 \\
\hline $\mathrm{NO}_{3}^{-} / \mathrm{mgl}^{-1}$ & 2 & 6 & 7 & 2 & 4.4 & 6 & 6.3 & 5.6 \\
\hline $\mathrm{PO}_{4}^{-3} / \mathrm{mg} \mathrm{|}^{-1}$ & 0.35 & $\div$ & $\div$ & 0.33 & $\div$ & $\div$ & $\div$ & $\div$ \\
\hline $\mathrm{NH}_{3}{ }^{-} / \mathrm{mgl}^{-1}$ & 0.09 & $\div$ & $\div$ & 0.03 & $\div$ & $\div$ & $\div$ & $\div$ \\
\hline
\end{tabular}

$(\div)$ immeasurable by spectrophotometer

$(\div)$ znak označava da spektrofotometar ne može analizirati vrijednost tog uzorka jer je izvan mjerne kontrole instrumenta 


\subsection{Results for chemical oxygen demand (COD)}

Chemical oxygen demand (COD) as a chemical parameter indicates in some way whether a sample is chemically contaminated or not. In our case, during the COD research on rivers (Fig. 1), there is no chemical contamination based on the results obtained in the laboratory. In the $\mathrm{SP}_{1}$ sample, COD value was $0.12 \mathrm{mgl}^{-1}$, but at the exit of the village, the COD in the $\mathrm{SP}_{2}$ sample was $3.36 \mathrm{mgl}^{-1}$, so there was a rapid increase in $\mathrm{COD}$, while in $\mathrm{SP}_{3}$ sample at the exit of the city, COD value was $1.7 \mathrm{mgl}^{-1}$ (Table 2). In the Stanishor River basin, COD was higher than in the samples contaminated with water, and the COD value in the $\mathrm{SP}_{4}$ sample reached $4.94 \mathrm{mgl}^{-1}$. In the $\mathrm{SP}_{5}$ samples, $\mathrm{COD}$ was $0.13 \mathrm{mgl}^{-1}$, while in the $\mathrm{SP}_{6}$ sample, the amount of COD was $3.1 \mathrm{mgl}^{-1}$. The COD of sample $\mathrm{SP}_{7}$ was $2.7 \mathrm{mgl}^{-1}$ and this sample was taken from a greater distance compared to sample $\mathrm{SP}_{6}$. Sample $\mathrm{SP}_{8}$ was taken in the Morava River, in which COD value was $1.34 \mathrm{mg} \mathrm{I}^{-1}$. Therefore, according to all mentioned results, the highest COD value was found in sample $\mathrm{SP}_{4}$ of the Stanishor River, but COD as a chemical parameter was higher in the Mirusha River than in the Stanishor River. In conclusion, all of these values are not in accordance with EU and WHO regulations (Table 1).

\subsection{Results for 5-day biochemical oxygen demand (BOD5)}

Biochemical oxygen demand (BOD) is a very important parameter to determine the biological level of water pollution. BOD5 in sample $\mathrm{SP}_{1}$ was $0 \mathrm{mg} \mathrm{l}^{-1}$, but during the flow of water from the Mirusha River site to the village exit, the amount of BOD5 in sample $\mathrm{SP}_{2}$ was as high as $20 \mathrm{mg} \mathrm{l}^{-1}$. In sample $\mathrm{SP}_{3}$, BOD5 was $18 \mathrm{mg} \mathrm{I}^{-1}$, so from $\mathrm{SP}_{2}$ to $\mathrm{SP}_{3}$ sampling site, the amount of BOD5 reduced by $2 \mathrm{mg} \mathrm{l}^{-1}$. BOD5 in sample $\mathrm{SP}_{4}$, which was the source of the Stanishor River, was $0 \mathrm{mgl}^{-1}$, while in sample $\mathrm{SP}_{5}$ the amount of BOD5 was $17 \mathrm{mgl}^{-1}$, a very large increase compared to the BOD5 of the Stanishor River basin. In sample $\mathrm{SP}_{6}, \mathrm{BOD} 5$ was $21 \mathrm{mgl}^{-1}$ (Table 2). BOD5 in sample $\mathrm{SP}_{7}$ was $0.2 \mathrm{mgl}^{-1}$. This is a very large drop in the biochemical consumption of oxygen, but in the Morava River, unfortunately, the quantity of BOD5 was $29 \mathrm{mgl}^{-1}$ and the value was higher than all other analysed samples. The lower and higher values of BOD5 are divided into two groups:

(i) In the first group with the locations $\mathrm{SP}_{1}, \mathrm{SP}_{4}$ and $\mathrm{SP}_{7}$ (Fig. 1), BOD5 values range from 0 to $0.2 \mathrm{mgl}^{-1}$, which is in accordance with $\mathrm{EU}$ and $\mathrm{WHO}$ regulations.

(ii) In the second group with $\mathrm{SP}_{2}, \mathrm{SP}_{3}, \mathrm{SP}_{5}, \mathrm{SP}_{6}$ and $\mathrm{SP}_{8}$ locations, BOD5 values range from 18 to $29 \mathrm{mgl}^{-1}$, indicating extreme contamination because $>10 \mathrm{mgl}^{-1}$ was calculated as extreme contamination. These values are not in accordance with EU and WHO regulations (Tables 1 and 2).

\subsection{Results for alkalinity}

All samples from $\mathrm{SP}_{1}$ to $\mathrm{SP}_{8}$ had $\mathrm{HCl}$ values from 5.5 to $7.8 \mathrm{ml}$ (Table 2), so there was no need for analysis of this parameter, because all the values were in accordance with EU and WHO regulations (Table 1).

\subsection{Results for bicarbonates $\mathrm{HCO}_{3}^{-}$}

During the determination of $\mathrm{HCO}_{3}{ }^{-}$, it can be seen that from one sampling point to another, its value had increased. In sample $\mathrm{SP}_{1}, \mathrm{HCO}_{3}{ }^{-}$value was $372.1 \mathrm{mg} \mathrm{l}^{-1}$, while in sample $\mathrm{SP}_{2}, \mathrm{HCO}_{3}{ }^{-}$was $414.8 \mathrm{mg} \mathrm{l}^{-1}$. In sample $\mathrm{SP}_{3}$, there was a decrease in $\mathrm{HCO}_{3}{ }^{-}$value $\left(408.7 \mathrm{mg} \mathrm{l}^{-1}\right)$ compared to the $\mathrm{SP}_{1}$ and $\mathrm{SP}_{2}$ samples. At the $\mathrm{SP}_{4}$ site, $\mathrm{HCO}_{3}{ }^{-}$was $335.5 \mathrm{mgl}^{-1}$, but at the exit of the city where sample $\mathrm{SP}_{5}$ was taken, $\mathrm{HCO}_{3}{ }^{-}$value was $427 \mathrm{mgl}^{-1}$, i.e., a higher $\mathrm{HCO}_{3}{ }^{-}$value compared to sample $\mathrm{SP}_{4}$, which was taken at the Stanishor River basin. The amount of $\mathrm{HCO}_{3}{ }^{-}$ in sample $\mathrm{SP}_{6}$ was $457.5 \mathrm{mgl}^{-1}$, while sample $\mathrm{SP}_{7}$ showed an increase in $\mathrm{HCO}_{3}{ }^{-}$up to $475.8 \mathrm{mg} \mathrm{I}^{-1}$. Morava River possess lower $\mathrm{HCO}_{3}{ }^{-}$value compared to all other samples, while only in sample $\mathrm{SP}_{8}$ the value reached $341.6 \mathrm{mg} \mathrm{I}^{-11}$ (Table 2). Bicarbonates in all samples from $\mathrm{SP}_{1}$ to $\mathrm{SP}_{8}$ are in accordance with EU and WHO regulations (Table 1).

\subsection{Results for general hardness and carbon strength}

Water containing a large amount of dissolved salts of alkaline earth metals is called strong water as opposed to soft water in which the amount of these salts is low. General hardness $(\mathrm{GH})$ in all samples from $\mathrm{SP}_{1}$ to $\mathrm{SP}_{8}$ enters the strongest water category, where $\mathrm{GH}$ value ranges from 15.28 to $21^{\circ} \mathrm{dH}$. In sample $\mathrm{SP}_{1}$, the $\mathrm{GH}$ value was $19.3^{\circ} \mathrm{dH}$, but this value began to drop in samples $\mathrm{SP}_{2}\left(17.41^{\circ} \mathrm{dH}\right)$ and $\mathrm{SP}_{3}\left(17.92^{\circ} \mathrm{dH}\right)$. In sample $\mathrm{SP}_{4}, \mathrm{GH}$ value was $19.42^{\circ} \mathrm{dH}$, but was lower in sample $\mathrm{SP}_{5}$ with a value of $18.42{ }^{\circ} \mathrm{dH}$. The $\mathrm{GH}$ in sample $\mathrm{SP}_{6}$ was $20.16^{\circ} \mathrm{dH}$, and in sample $\mathrm{SP}_{7}$ it was $21^{\circ} \mathrm{dH}$, which is higher compared to sample $\mathrm{SP}_{5}$, while in sample $\mathrm{SP}_{8}$ the $\mathrm{GH}$ value decreased to $15.28{ }^{\circ} \mathrm{dH}$. All $\mathrm{GH}$ values of the aforementioned samples $\mathrm{SP}_{1}-\mathrm{SP}_{8}$ (Fig. 1) are not included in the category of very strong water at the German ${ }^{\circ} \mathrm{dH}$ degree. The water of Stanishor River was harder compared to the $\mathrm{GH}$ of Mirusha River.

Large amounts of sodium bicarbonate or potassium in water will result in greater carbonate hardness than total strength $(\mathrm{GH})$. Carbon strength (CS) values in the analysed samples ranged from 15.4 to $21.8^{\circ} \mathrm{dH}$ to $\mathrm{SP}_{1}-\mathrm{SP}_{8}$ samples (Fig. 1). In sample $\mathrm{SP}_{1}, \mathrm{CS}$ value was $17.08^{\circ} \mathrm{dH}$, in sample $\mathrm{SP}_{2}, \mathrm{CS}$ value was $19.4^{\circ} \mathrm{dH}$. It can be seen that sodium or potassium bicarbonates are higher in $\mathrm{SP}_{2}$ than in $\mathrm{SP}_{1}$, while CS is reduced in sample $\mathrm{SP}_{3}$ at $18.7^{\circ} \mathrm{dH}$ compared to $\mathrm{SP}_{2}$. The CS value in sample $\mathrm{SP}_{4}$ at the Stanishor River was $15.4^{\circ} \mathrm{dH}$, but in $\mathrm{SP}_{5}$ at the exit of the Stanishor River, CS value was $19.6^{\circ} \mathrm{dH}$, thus, the CS increased compared to that of $\mathrm{SP}_{4}$. In sample $\mathrm{SP}_{6}, \mathrm{CS}$ value again increased to $21^{\circ} \mathrm{dH}$ compared to $\mathrm{SP}_{3}$ and $\mathrm{SP}_{5}$. The $\mathrm{CS}$ value of $\mathrm{SP}_{7}$ was $21.8^{\circ} \mathrm{dH}$, but in $\mathrm{SP}_{8}$ of the Morava River, CS value was reduced at $15.28{ }^{\circ} \mathrm{dH}$. Finally, CS was the highest in the Stanishor River and the lowest in the Mirusha and Morava Rivers (Table 2). $\mathrm{GH}$ and $\mathrm{CS}$ values in $\mathrm{SP}_{1}-\mathrm{SP}_{8}$ samples do not present a risk and are in accordance with EU and WHO regulations (Table 1). 


\subsection{Results for calcium $\left(\mathrm{Ca}^{2+}\right)$}

Calcium $\left(\mathrm{Ca}^{2+}\right)$ is a very important parameter for water. In our case, its value ranged from 61.7 to $140.28 \mathrm{mg} \mathrm{l}^{-1}$ for $\mathrm{SP}_{1}-\mathrm{SP}_{8}$ (Fig. 1). In $\mathrm{SP}_{1}$ of the Mirusha River basin, $\mathrm{Ca}^{2+}$ value was $61.7 \mathrm{mgl}^{-1}$, in $\mathrm{SP}_{2}$ the value of $\mathrm{Ca}^{2+}$ was $126.2 \mathrm{mgl}^{-1}$, and in $\mathrm{SP}_{3}$ near the merging point with the Stanishor River, the value of $\mathrm{Ca}^{2+}$ was $129.05 \mathrm{mgl}^{-1}$. In $\mathrm{SP}_{4}$ at the Stanishor River basin, the amount of $\mathrm{Ca}^{2+}$ was $122.88 \mathrm{mgl}^{-1}$, and in $\mathrm{SP}_{5}$ the $\mathrm{Ca}^{2+}$ value was $140.28 \mathrm{mgl}^{-1}$, thus, the amount of calcium increased in value from the river source to the interconnection between the two rivers - Mirusha and Stanishor. The $\mathrm{Ca}^{2+}$ value in $\mathrm{SP}_{6}$ was $140.8 \mathrm{mgl}^{-1}$ and, compared to the sample of the Mirusha and Stanishor River after mixing these two rivers, $\mathrm{Ca}^{2+}$ value increased. In $\mathrm{SP}_{7}$, the amount of $\mathrm{Ca}^{2+}$ did not change significantly compared to $\mathrm{SP}_{5}$ and $\mathrm{SP}_{6}$. In $\mathrm{SP}_{8}$ of the Morava River, the $\mathrm{Ca}^{2+}$ content was $102 \mathrm{mgl}^{-1}$, so the amount of $\mathrm{Ca}^{2+}$ in this river was reduced to $38 \mathrm{mgl}^{-1}$ compared to $\mathrm{SP}_{7}$ (Table 2). The $\mathrm{Ca}^{2+}$ values in this river are in accordance with $\mathrm{EU}$ and $\mathrm{WHO}$ regulations (Table 1 ).

\subsection{Results for magnesium $\left(\mathrm{Mg}^{2+}\right)$}

Magnesium $\left(\mathrm{Mg}^{2+}\right)$ ions values in samples $\mathrm{SP}_{1}-\mathrm{SP}_{8}$ (Fig. 1) were not very high, ranging from 20.6 to $56.7 \mathrm{mgl}^{-1}$. In $\mathrm{SP}_{1}$ of the Mirusha River basin, $\mathrm{Mg}^{2+}$ value was $56.7 \mathrm{mgl}^{-1}$, which was higher than that of all other samples analysed in the laboratory. In sample $\mathrm{SP}_{2}, \mathrm{Mg}^{2+}$ value decreases (20.6 $\mathrm{mg} \mathrm{l}^{-1}$ ) compared to $\mathrm{SP}_{1}$. The value of $\mathrm{Mg}^{2+}$ in $\mathrm{SP}_{3}$ was $21.6 \mathrm{mgl}^{-1}$, which was higher by $1 \mathrm{mgl}^{-1}$ in comparison to $\mathrm{SP}_{2}$. In $\mathrm{SP}_{4}$ of the Stanishor River basin, the amount of $\mathrm{Mg}^{2+}$ was $31.02 \mathrm{mg} \mathrm{l}^{-1}$, but in $\mathrm{SP}_{5}$ of the Stanishor River, the amount of $\mathrm{Mg}^{2+}$ decreased to $18.9 \mathrm{mgl}^{-1}$. In $\mathrm{SP}_{6}$, $\mathrm{Mg}^{2+}$ value was $26.4 \mathrm{mg} \mathrm{l}^{-1}$, much lower compared to $\mathrm{SP}_{1}$ and $\mathrm{SP}_{4}$ at the Mirusha and Stanishor River basins (Table 2). In $\mathrm{SP}_{7}, \mathrm{Mg}^{2+}$ value was $30.07 \mathrm{mgl}^{-1}$, which was higher than that of $\mathrm{SP}_{6}$. In $\mathrm{SP}_{8}$ of Morava River, $\mathrm{Mg}^{2+}$ value was $21.9 \mathrm{mgl}^{-1}$. $\mathrm{Mg}^{2+}$ values of the river waters are in accordance with EU and WHO regulations (Table 1).

\subsection{Results for chlorides ( $\left.\mathrm{Cl}^{-}\right)$}

During laboratory analysis, chlorides $\left(\mathrm{Cl}^{-}\right)$were 12.3$73.9 \mathrm{mg} \mathrm{l}^{-1}$ in $\mathrm{SP}_{1}-\mathrm{SP}_{2}$ (Fig. 1). In $\mathrm{SP}_{1}, \mathrm{Cl}^{-}$value was $12.3 \mathrm{mgl}^{-1}$, and in $\mathrm{SP}_{2} \mathrm{Cl}^{-}$was $72 \mathrm{mgl}^{-1}$. It can be seen that the amount of $\mathrm{Cl}^{-}$increased in $\mathrm{SP}_{2}$ by $59.7 \mathrm{mg} \mathrm{l}^{-1}$ compared to $\mathrm{SP}_{1}$. In $\mathrm{SP}_{3}$, the amount of $\mathrm{Cl}^{-}$was $68 \mathrm{mgl}^{-1}$, so there was a decrease in the amount of $\mathrm{Cl}^{-}$in comparison to $\mathrm{SP}_{2}$. In $\mathrm{SP}_{4}$ taken at the Stanishor River basin, $\mathrm{Cl}^{-}$ value was $29.9 \mathrm{mgl}^{-1}$, so the amount of $\mathrm{Cl}^{-}$was higher compared to the Mirusha River basin in $\mathrm{SP}_{1}$ (Table 2). In $\mathrm{SP}_{5}, \mathrm{Cl}^{-}$value was $51.9 \mathrm{mgl}^{-11}$, so the value was higher compared to $\mathrm{SP}_{4}$. The amount of $\mathrm{Cl}^{-}$in $\mathrm{SP}_{6}$ that was collected after the merging of the Mirusha and Stanishor rivers, was $52.2 \mathrm{mgl}^{-1}$, while in $\mathrm{SP}_{7}$, the amount of $\mathrm{Cl}^{-}$was $73.9 \mathrm{mg} \mathrm{l}^{-1}$ which was higher than that in $\mathrm{SP}_{6}$, while in the $\mathrm{SP}_{8}$ sample of the Morava River, the value of $\mathrm{Cl}^{-}$was $36 \mathrm{mgl}^{-1}$, which is very low compared to $\mathrm{SP}_{7}$ (Table 2). The value of $\mathrm{Cl}^{-}$poses no pollution risk, and is in accordance with the allowed EU and WHO values (Table 1).

\subsection{Results for chlorine $\left(\mathrm{Cl}_{2}\right)$}

Chloride $\left(\mathrm{Cl}_{2}\right)$ was determined at sites where $\mathrm{SP}_{1}-\mathrm{SP}_{8}$ samples were taken (Fig. 1). $\mathrm{Cl}_{2}$ was defined because if in these waters $\mathrm{Cl}_{2}$ exceeds $0.5 \mathrm{mgl}^{-1}$, the potential to form trihalomethans would be very high. Trihalomethans are very dangerous and are formed by the very high amount of chlorine used in the regional water supply system. Sample $\mathrm{SP}_{1}$ cannot normally be $\mathrm{Cl}_{2}$ because it is the source of the Mirusha River that originates from the subsoil. In sample $\mathrm{SP}_{2}$, the $\mathrm{Cl}_{2}$ value was $0.21 \mathrm{mg} \mathrm{l}^{-1}$, while in $\mathrm{SP}_{3}$ the value of $\mathrm{Cl}_{2}$ increased to $0.26 \mathrm{mg} \mathrm{l}^{-1}$ compared to $\mathrm{SP}_{2}$, and this increase in $\mathrm{Cl}_{2}$ in sample $\mathrm{SP}_{3}$ occurred due to the release of domestic waters supplied by the regional water supply. In $\mathrm{SP}_{4}, \mathrm{Cl}_{2}$ value was $0 \mathrm{mgl}^{-1}$ because it is the source of the Stanishor River that originates from the subsoil. In $\mathrm{SP}_{5}$, the amount of $\mathrm{Cl}_{2}$ was very low at $0.01 \mathrm{mgl}^{-1}$, while in $\mathrm{SP}_{6}$, where the two rivers meet, the amount of $\mathrm{Cl}_{2}$ was $0.07 \mathrm{mgl}^{-1}$. In $\mathrm{SP}_{7}, \mathrm{Cl}_{2}$ value was $0.39 \mathrm{mgl}^{-1}$, which is very high compared to $\mathrm{SP}_{6}$, and $\mathrm{SP}_{6}-\mathrm{SP}_{7}$ are not at a very large distance. In $\mathrm{SP}_{8}$ of Morava River, $\mathrm{Cl}_{2}$ value was $0.19 \mathrm{mgl}^{-1}$, lower compared to sample $\mathrm{SP}_{7}$ (Table 2). $\mathrm{Cl}_{2}$ value in these samples are in accordance with allowed EU and WHO values (Table 1).

\subsection{Results for nitrites $\left(\mathrm{NO}_{2}^{-}\right)$}

The laboratory analysis of nitrite $\left(\mathrm{NO}_{2}{ }^{-}\right)$raised concerns, because high values in all the samples, $\mathrm{SP}_{1}-\mathrm{SP}_{8}$, were determined. In $\mathrm{SP}_{1}$ of the Mirusha River basin, $\mathrm{NO}_{2}{ }^{-}$value was $1 \mathrm{mgl}^{-1}$, whereas the $\mathrm{EU}$ and WHO standards permit $\mathrm{NO}_{2}^{-}$amounts up to $0.6 \mathrm{mgl}^{-1}$ (Table 1 ). In sample $\mathrm{SP}_{2}, \mathrm{NO}_{2}^{-}$value increased to $16 \mathrm{mgl}^{-1}$, while in $\mathrm{SP}_{3}$ taken at the exit of the city, $\mathrm{NO}_{2}^{-}$value was $11 \mathrm{mgl}^{-1}$. If we compare $\mathrm{NO}_{2}{ }^{-}$values from the Mirusha River basin, the amount of nitrite increased significantly, which is very disturbing (Table 2). In $\mathrm{SP}_{4}$ taken at the Stanishor River ba$\sin , \mathrm{NO}_{2}{ }^{-}$value was $4 \mathrm{mg} \mathrm{l}^{-1}$, which is a very high value from a non-polluted wastewater source, while in $\mathrm{SP}_{5}$ the $\mathrm{NO}_{2}{ }^{-}$value was $13 \mathrm{mgl}^{-1}$. If we compare the $\mathrm{NO}_{2}{ }^{-}$value from the Stanishor River source with sample $\mathrm{SP}_{4}$ up to peak $\mathrm{SP}_{5}, \mathrm{NO}_{2}{ }^{-}$value increased by $9 \mathrm{mgl}^{-1}$. In $\mathrm{SP}_{6}$ taken at the intersection of the two rivers (Fig. 1), $\mathrm{NO}_{2}{ }^{-}$value was $12 \mathrm{mgl}^{-1}$, while at a greater distance in $\mathrm{SP}_{7}$ the nitrite value was $2 \mathrm{mg} \mathrm{l}^{-1}$. In sample $\mathrm{SP}_{7}$, the nitrites significantly decreased, but still exceeded the permitted regulatory range for this parameter. In sample $\mathrm{SP}_{8}$ taken from the Morava River, $\mathrm{NO}_{2}^{-}$value was $13 \mathrm{mgl}^{-1}$, so even in this river, the amount of nitrite is high. In conclusion, $\mathrm{NO}_{2}^{-}$values in these samples are not in accordance with $\mathrm{EU}$ and $\mathrm{WHO}$ regulations (Table 1 ).

\subsection{Results for nitrates $\left(\mathrm{NO}_{3}{ }^{-}\right)$}

The laboratory analysis of nitrates $\left(\mathrm{NO}_{3}{ }^{-}\right)$showed that $\mathrm{NO}_{3}{ }^{-}$values ranged from 2 to $7 \mathrm{mg} \mathrm{l}^{-1}$ in $\mathrm{SP}_{1}-\mathrm{SP}_{8} . \mathrm{NO}_{3}{ }^{-}$ value in $\mathrm{SP}_{1}$ was $2 \mathrm{mg} \mathrm{l}^{-1}$, while in $\mathrm{SP}_{2}$, the $\mathrm{NO}_{3}{ }^{-}$value was $6 \mathrm{mgl}^{-1}$, which shows an increase in the amount of nitrate compared to $\mathrm{SP}_{1}$ at the Mirusha River source. In $\mathrm{SP}_{3}$, nitrates were $7 \mathrm{mgl}^{-1}$. Compared to $\mathrm{SP}_{2}$, the $\mathrm{NO}_{3}{ }^{-}$ value increased by $1 \mathrm{mgl}^{-1}$ in $\mathrm{SP}_{3}$. In $\mathrm{SP}_{4}$ of the Mirusha 
River basin, the nitrate value was $2 \mathrm{mg} \mathrm{I}^{-1}$, whereas (Table 2) $\mathrm{NO}_{3}{ }^{-}$value in $\mathrm{SP}_{5}$ was $4.4 \mathrm{mgl}^{-1}$, so in $\mathrm{SP}_{5}$ the nitrate value increased to $2.2 \mathrm{mgl}^{-1}$ compared to $\mathrm{SP}_{4}$. In $\mathrm{SP}_{6}$ (Fig. 1), $\mathrm{NO}_{3}^{-}$value was $6 \mathrm{mgl}^{-1}$, so it can be seen that after merging of the Mirusha and Stanishor rivers, the nitrate values increased, while in $\mathrm{SP}_{7}$ the value of $\mathrm{NO}_{3}{ }^{-}$again rose to $6.3 \mathrm{mgl}^{-1}$. In $\mathrm{SP}_{8}$, the $\mathrm{NO}_{3}^{-}$value was $5.6 \mathrm{mgl}^{-1}$, which was less than that of $\mathrm{SP}_{7}$ (Table 2). The $\mathrm{NO}_{3}{ }^{-}$values are in accordance with EU and WHO regulations (Table 1), and present no concern.

\subsection{Results for phosphates $\left(\mathrm{PO}_{4}{ }^{3-}\right)$}

During spectrophotometric analysis of phosphate $\mathrm{PO}_{4}{ }^{3-}$ in the laboratory, as referred to in method 8048, the maximum measuring range of the instrument with this method is $2.5 \mathrm{mg} \mathrm{I}^{-1}$. In $\mathrm{SP}_{1}$ of the Mirusha River basin, $\mathrm{PO}_{4}{ }^{3-}$ value was $0.35 \mathrm{mgl}^{-1}$, whereas in $\mathrm{SP}_{2}$, the $\mathrm{PO}_{4}{ }^{3-}$ value was outside the instrument's measuring range, i.e. it was higher than $2.5 \mathrm{mgl}^{-1}$, and in $\mathrm{SP}_{3}$ it was impossible for the spectrophotometer to give a value of $\mathrm{PO}_{4}{ }^{3-}$ because the value was outside the measuring range. In $\mathrm{SP}_{4}$ taken from the Stanishor River basin, the value of $\mathrm{PO}_{4}{ }^{3-}$ was $0.33 \mathrm{mgl}^{-1}$, while in $\mathrm{SP}_{5}, \mathrm{SP}_{6}, \mathrm{SP}_{7}$, and $\mathrm{SP}_{8}$, the values of phosphates $\left(\mathrm{PO}_{4}{ }^{3-}\right)$ were immeasurable as mentioned above. The phosphate was divided into two groups of samples due to the high pollution present in these rivers (Fig. 1):

(i) The first group of samples that included $\mathrm{SP}_{1}$ and $\mathrm{SP}_{3}$ taken from the Mirusha and Stanishor river basins are not in accordance with EU and $\mathrm{WHO}$ regulations, but reveal lower values compared to the second group (Table 2);

(ii) The second group of samples $\mathrm{SP}_{2}, \mathrm{SP}_{4}, \mathrm{SP}_{5}, \mathrm{SP}_{6}, \mathrm{SP}_{7}$, and $\mathrm{SP}_{8}$ includes values over $2.5 \mathrm{mg} \mathrm{l}^{-1}$ that are not in accordance with EU and WHO regulations (Table 1).

\subsection{Results for ammonia $\left(\mathrm{NH}_{3}^{-}\right)$}

Ammonia $\left(\mathrm{NH}_{3}{ }^{-}\right)$is a very important parameter to define in waters or sewage because amounts exceeding the limits should raise great concern. In $\mathrm{SP}_{1}$ of the Mirusha River basin, $\mathrm{NH}_{3}{ }^{-}$value was $0.09 \mathrm{mgl}^{-1}$ and in $\mathrm{SP}_{4}$ of the Stanishor River basin, it was $0.03 \mathrm{mg} \mathrm{l}^{-1}$, whereas in other samples it was immeasurable because it was outside the metering range or spectrophotometric determinant. The lowest and the highest values of $\mathrm{NH}_{3}{ }^{-}$are divided into two groups:

(i) The first group that includes $\mathrm{SP}_{4}$ of the Stanishor River is in accordance with $\mathrm{EU}$ and $\mathrm{WHO}$ regulations (Table 1).

(ii) The second group, all samples including $\mathrm{SP}_{1}, \mathrm{SP}_{2}, \mathrm{SP}_{3}$, $\mathrm{SP} 5, \mathrm{SP}_{6}$, and $\mathrm{SP}_{7}$ are not in accordance with $\mathrm{EU}$ and WHO regulations (Tables 1 and 2).

\section{Conclusion}

Based on the results, the studied river waters are heavily contaminated with nitrites, ammonium ions, phosphate ions, and BOD5. The water pollution of these rivers, as mentioned above, is caused by discharges from households, the food industry, and the application of chemicals in agriculture. Concentrations beyond the reference values of these pollutants directly affects the flora and fauna of the river waters, and thus are fatal for aquatic life. The primary goal of every state, and of Kosovo, is to protect the quality of water, and precisely for this reason, the state institutions, both at local and central level, should not only be committed to the permanent monitoring of these river waters, but should also construct an implant structure, where the Mirusha and Stanishor rivers merge with the waters of Morava River.

Discussion of the results and comparison of different parameters of $\mathrm{SP}_{1}-\mathrm{SP}_{8}$ samples was very important in order to gain insight into how the parameters deviate. According to our research, the main problem of deviation was the purification of industrial pipes with the CIP system, since all the waters containing a large number of microorganisms are released into these rivers, resulting in extreme pollution due to the lack of wastewater treatment plants in the processing industry.

\section{List of abbreviations \\ Popis kratica}

$$
\begin{array}{ll}
\text { BOD5 } & \text { - 5-day biochemical oxygen demand } \\
& \text { - petodnevna biokemijska potrošnja kisika } \\
\text { CIP } & \text { - Clean-in-place } \\
& \text { - CIP čišćenje } \\
\text { COD } & \text { - chemical oxygen demand } \\
& \text { - kemijska potrošnja kisika } \\
\text { CS } & \text { - carbonic strength } \\
& \text { - ugljična čvrstoća } \\
\text { CW } & \text { - conductivity of water } \\
& \text { - vodljivost vode } \\
\text { DO } & \text { - dissolved oxygen } \\
& \text { - otopljeni kisik } \\
\text { EDTA } & \text { - ethylenediaminetetraacetic acid } \\
& \text { - etilendiamintetraoctena kiselina } \\
\text { GH } & \text { - general hardness } \\
& \text { - ukupna tvrdoća } \\
\text { ISO } & \text { - International Organization for Standardization } \\
& \text { - Međunarodna organizacija za standardizaciju } \\
\text { NTU } & \text { - nephelometric turbidity unit } \\
& \text { - nefelometarska jedinica mutnoće } \\
\text { SP } & \text { - sample } \\
& \text { - uzorak }
\end{array}
$$




\section{References \\ Literatura}

1. B. Korça, Analiza kimike e ujit, Prishtinë, 2013, pp. 91-92, 95, 97, 99-100.

2. A. Çullaj, Kimi mjedisi, Tiranë, 2005, pp. 13-14.

3. N. R. Rexhepi, Mbrojtja e ambientit për jetë më të mirë, Prishtinë, 2006, p. 22

4. N. M. Daci, Kima e mjedisit, Prishtinë, 1998, p. 30.

5. I. Filipoviq, S. Lipanoviq, Kimia inorganike, Prishtinë, 1997, p. 730.

6. N. M. Daci, M.N. Daci-Ajvazi, Shkenca e mjedisit, Prishtinë, 2014, pp. 234, 238, 249, 253, 255, 260, 264.

7. F. Ahmedi, Teknologjia e trajtimit të ujërave, Prishtinë, 2010, pp. 11, 13.
8. D. F. Shriver, P.W. Atkins, Kimia inorganike, Oxford, 2009, p. 765 .

9. J. W. Hill, R. H. Petrucci, T. W. McCreary, S. S. Perry, Kima e Përgjithshme, SHBA, 2014, p. 1052.

10. V. Beluli, Thesis, Shkalla e përqendrimit të metaleve të rënda në lumenjtë Mirushë e Stanishor të komunës së Gjilanit dhe ndikimi i tyre në ujërat e lumit Moravë, Mitrovicë, Kosovë, 2017, pp. 21, 35

11. M. Vasjari, A. Shehu, B. Baraj, A. Çullaj, Metodat instrumentale të analizës, Tiranë, 2013, p. 52

12. P. Lazo, A. Çullaj, Metoda të analizës instrumentale, Tiranë, 2017 , p. 59

13. DR/2010 Spectrophotometer instrument manual, general description, USA, 1999, p. 15.

14. M. Aliu, Teknologjia e ujit, Mitrovicë, 2017, p. 20.

\section{SAŽETAK \\ Utjecaj urbanizacije i industrije na onečišćenje rijeka općine Gjilan, Kosovo \\ Valdrin M. Beluli}

Grad Gjilan $\left(42^{\circ} 28^{\prime} 08^{\prime \prime}, \mathrm{V} 21^{\circ} 27^{\prime} 48^{\prime \prime} \mathrm{L}\right)$ jedan je od sedam najvećih gradova na Kosovu. Kroz njega prolaze tri rijeke: Mirusha i Stanishor koje se miješaju i ulijevaju u najveću rijeku Moravu. Razlog za istraživanje tih rijeka je njihovo onečišćenje nastalo ispuštanjem industrijskih voda. Analiza tih rijeka pokazuje izrazito onečišćenje te neusklađenost nekih fizikalno-kemijskih parametara s propisima Europske unije (EU) i Svjetske zdravstvene organizacije (SZO). Analizirani su sljedeći parametri: pH, CW, NTU, DO, COD, BOD5, A-HCl, $\mathrm{HCO}_{3}, \mathrm{GH}, \mathrm{CS}, \mathrm{Cl}^{-}, \mathrm{Cl}_{2}, \mathrm{Ca}^{2+}, \mathrm{Mg}^{2+}, \mathrm{NO}_{2}^{-}$, $\mathrm{NO}_{3}{ }^{-}, \mathrm{PO}_{4}{ }^{3-} \mathrm{i} \mathrm{NH}_{3}{ }^{-}$.

Ključne riječi

Rijeke, industrije, izrazito onečišćenje, fizikalno-kemijski parametri, EU, SZO

Univerzitet u Mitrovici "Isa Boletini"

Stručni rad

Prehrambeno tehnološki fakultet

Prispjelo 9. travnja 2018.

Odjel za tehnologiju

Prihvaćeno 12. lipnja 2018.

Kosovo 